\title{
Analysis of the Mechanical Properties of Natural Composites Matoa Tree Wood as the Foundation for Environmentally Friendly House Piles
}

\author{
Eko Tavip Maryanto \\ Civil Engineering \\ University of Muhammadiyah Education Sorong \\ Sorong, 98418, Indonesia \\ ekotavipm@gmail.com \\ Rezza Ruzuqi \\ Fisheries Mechanization \\ Marine and Fisheries Polytechnic of Sorong \\ Sorong, 98411, Indonesia \\ Rezza.ruzuqi31@gmail.com
}

\begin{abstract}
Composite materials, in simple terms, are materials that have a multi-phase system composed of reinforcing materials and matrix materials. Composite materials are divided into two types, namely synthetic composite materials and natural composite materials. Wood is a natural composite material consisting of a reinforcement and a matrix. The wood of the matoa tree (Pometia vinnata) is known for its good mechanical strength. The comparison of compressive mechanical strength in this study was conducted on matoa wood and ironwood tree wood (eusideroxylon zwageri). This was performed as supporting data in the discussion of natural composite materials of matoa tree wood as the foundation for environmentally friendly house piles. The results obtained were matoa wood and ironwood, respectively $\mathrm{A} 1=6.07 \mathrm{e}^{\wedge}(-07) \mathrm{MPa}, \mathrm{A} 2=1.11 \mathrm{e}^{\wedge}(-06) \mathrm{MPa}$, and $\mathrm{A} 3=2.09 \mathrm{e}^{\wedge}(-06) \mathrm{MPa}$ and $\mathrm{B} 1=1.17 \mathrm{e}^{\wedge}(-06) \mathrm{MPa}$, $\mathrm{B} 2=2.13 \mathrm{e}^{\wedge}(-06) \mathrm{MPa}$, and $\mathrm{B} 3=4.02 \mathrm{e}^{\wedge}(-06) \mathrm{MPa}$. These results indicated that the resistance to mechanical compression test of ironwood tree was greater than matoa tree. However, when it was seen based on the perspective of the impact on the environment, Matoa tree has environmentally friendly properties that are effective and efficient. This is supported by the nature of the matoa tree which is easy to cultivate and its roots do not damage other plants.
\end{abstract}

\section{Keywords}

Natural Composites, Matoa Tree Wood, Finite Element Method (FEM), Environmentally Friendly

\section{Introduction}

The design of ironwood natural composites is presented in this study to determine which natural composite materials are best applied to the people of West Papua. The design is taken from several literatures and direct field reviews. In the literature, the nature and design of retaining walls are determined. All geometric designs were completed using numerical methods. Due to the limited data bank of the mechanical properties of matoa and ironwood, the results obtained can contribute positively to the community.

\section{Literature Review}

Matoa or Taun is a fruit plant that is the identity of Papua flora, which is spread in almost every area, including: the Seko land (Jayapura), Wondoswaar-Weoswar Island, Anjai Kebar, Warmare, Armina-Bintuni, Ransiki, Pami-Nuni (Manokwari), Samabusa-Nabire, and the island of Yapen [1]. Matoa is known by various names, such as Kasai (North Kalimantan, Malaysia, Indonesia), Malugai (Philippines), and Taun (Papua New Guinea). While the regional names are Kasai, Kongkir, Kungkil, Ganggo, Lauteneng, Pakam (Sumatra); Galunggung, Jampango, Kasei, Landur (Kalimantan); Kase, Landung, Nautu, Laughter, Wusel (Sulawesi); Jagir, Leungsir, Sapen (Java); Hatobu, Matoa, 
Motoa, Loto, Ngaa, Tawan (Maluku); Iseh, Kauna, Keba, Maa, Muni (Nusa Tenggara); Ihi, Mendek, Mohui, Senai, Laughter, Tawang (Papua) [2].

Matoa tree is known to have sweet fruit, thus the fruit can be consumed. Besides that, matoa has other benefits, matoa leaf litter is used as mulch [3], matoa bark can be used as fabric dye [4]. Matoa is also used in the treatment of several diseases. Matoa bark is used as an antibacterial and antioxidant [5,6]. Since matoa has many benefits provided, these plants need to be preserved [7].

In addition to these known benefits, matoa tree has also been used for its wood for a long time. Red matoa tree wood is a type of wood that has characteristics. Matoa wood is famous for its sturdy fibers and has good mechanical properties compared to other types of wood, especially for timber tree species in the tropics [8]. This is supported by the existence of unique tree roots, which have a taproot but the branches do not interfere with other plants in the vicinity. It is in contrast to the taproot owned by the mango tree.

In Eastern Indonesia, especially West Papua, there are many uses of natural composite materials. This is due to the natural conditions that support it. Many abundant natural resources are still untouched. Most of these natural resources are used as foundation materials for residents' houses, for example natural composites of matoa tree wood. In addition to the use of matoa tree wood as a foundation, it is also used as household furniture as shown in Figure 1.
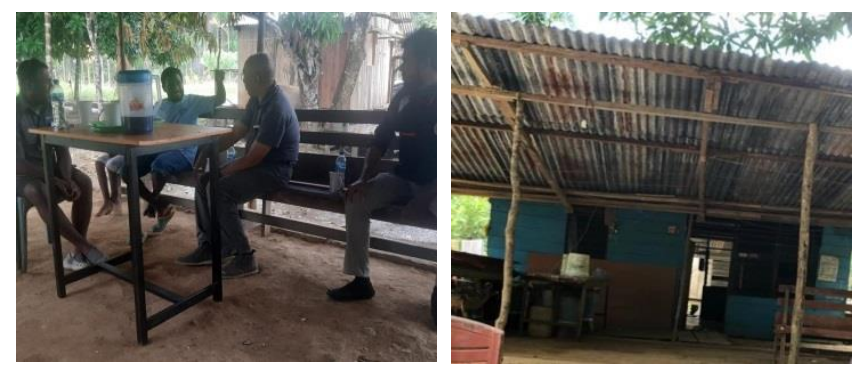

Figure 1. Utilization of matoa wood by the people of West Papua

The foundation of a house is very important for a building, because it has the main function to support the load of the building above it and pass it on to the soil at the bottom of a building. In designing the foundation, one has to pay attention to the details. There are various types of foundations for a building, one of them is a wooden foundation. The wooden foundation was chosen because the community wanted to maintain local wisdom and abundant natural wood resources.

People of West Papua are still strong in their local wisdom, the foundation design of the house still used natural composite materials as shown in Figure 1. The wooden foundation design has various forms, the shape of the pile foundation is the form commonly used by the community. Illustration of the design of the pile foundation used, as shown in Figure 2.

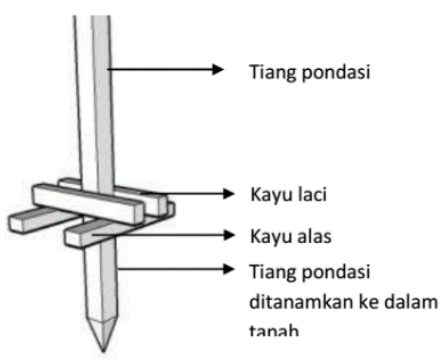

Figure 2. Illustration of commonly used foundation designs [11]

The foundation design is also widely used in other areas such as in South Kalimantan [9,10], West Kalimantan [11,12], and East Kalimantan [13]. The design was chosen because, the design is simple, appropriate with the surrounding area, and does not support heavy building loads. In addition, there are contours of swamp land (soft clay) and peat soil. Therefore, the pile foundation system was chosen since it is very adaptive to natural conditions.

Nowadays, environmentally friendly natural composite materials are very hard to find. Moreover, many synthetic composite materials were created to replace them. In terms of physical strength, natural composites are not inferior to synthetic composite materials. Many applications of natural composite materials, but some of them still use a mixture 
of synthetic polymers. This is because the number of natural composites is limited. Examples of applications of these mixed natural composites include gear shift knobs [14, 15], various automotive parts [16-19], and so on.

However, most of the natural wood composite materials used in building structures include reinforced soil bricks [20], construction materials [21], and building structural materials [22].

Commonly, to obtain the value of the mechanical strength of natural wood composites, it used experimental methods [23-31]. In this study, a numerical method is used to obtain the value. Finite Element Methods (FEM) was chosen because it is an easy-to-use method. The numerical methods commonly used are the finite element method [32-43] and the limit equilibrium method [44].

FEM can also be used to analyze the mechanical strength of wood-plastic composite materials [45], compressive, buckling strength of old wood reinforced with CFRP strips [29], Modeling of prestressed Glulam beams with compressed wood [46], and Modeling of modified foundation from dowel installation at the glulam joint [24].

The finite element method is a numerical procedure that can be used to find a solution to most engineering problems involving stress, heat transfer, electromagnetic and fluid flow analysis. It contains many complex forms of domain problems which can be solved easily [47].

In general, the finite element method (for some elements) is defined as:

$$
[K] T=\mathrm{f}
$$

where $[\mathrm{K}]$ is the matrix condition, or it can also be elaborated as:

$$
[\mathbf{K}]=K_{i j}=\int_{\Omega}\left[K_{x} \frac{\partial N_{i}}{\partial x} \frac{\partial N_{i}}{\partial x}+\frac{\partial N_{i}}{\partial y} \frac{\partial N_{i}}{\partial y} d \Omega\right]
$$

While $N_{-} i$ and $N_{j} j$ are the shape functions of the Moving Least Squares (MLS) row $i$ and column $j$, respectively, $T$ is a vector that describes nodal displacement and $\mathrm{f}$ is a vector that describes nodal forces and external forces, or it can also be described as:

$$
\boldsymbol{f}=F_{i}=\int_{\Omega} Q(x, y) N_{i} d \Omega+\int_{\Gamma} \bar{q} N_{i} d \Gamma
$$

The design of ironwood natural composites is presented in this study to determine which natural composite materials are best applied to the people of West Papua. The design is taken from several literatures and direct field reviews. In the literature, the nature and design of retaining walls are determined. All geometric designs were completed using numerical methods. Due to the limited data bank of the mechanical properties of matoa and ironwood, the results obtained can contribute positively to the community.

\section{Methods}

\subsection{Analyzed Pile Foundation}

Figure 3 showed the design analysis of pile foundations. This design is used on both matoa and ironwood types. The size and design of the test samples followed the literature of ASTM D-143 (Standard Test Methods for Small Clear Specimens of Timber). The design was used because it is also in accordance with field conditions. The design consists of a height and a width of $200 \mathrm{~mm}$ and $50 \mathrm{~mm}$, respectively. The design was subjected to a mechanical compression test to determine its strength.

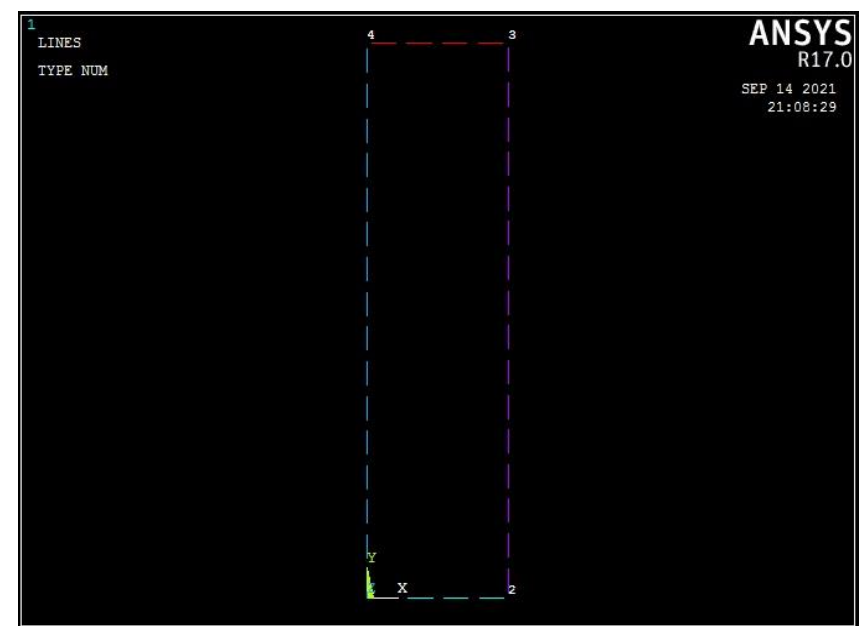

Figure 3. Tested wooden foundation design according to ASTM D-143

\subsection{Numerical models}


In this study, all retaining walls were modelled using Ansys 17.0 software running on the ASUS A451L Core i5 RAM $12 \mathrm{~GB}$ computer. Material properties and geometry were taken from various literature $[8,48]$ and the number of finite elements was determined by software. The calculation used in this study is a simple calculation. For Figure 4 shows, divided into three types having different number of finite elements, A1 64 elements, A2 256 elements and A3 1024 elements and Figure 5 shows, divided into three types having different number of finite elements, B1 64 elements, B2 256 elements and B3 1024 elements.

The two models have boundary conditions according to literature with the lower boundary condition considered constant. Besar kuat tekan yang diberikan, berdasarkan pada literatur. The results obtained are then compared in order to obtain the safety factor value of which retaining wall is the best.

A1

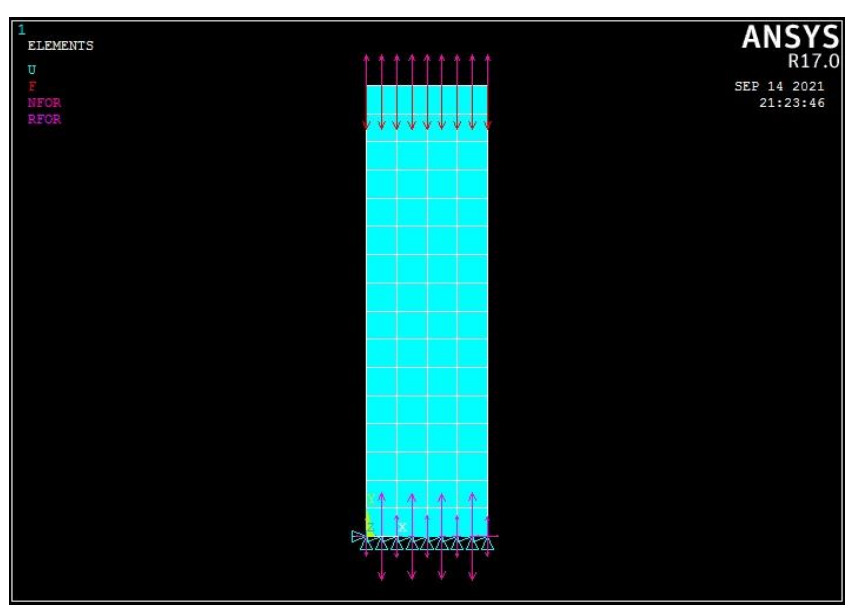

A2

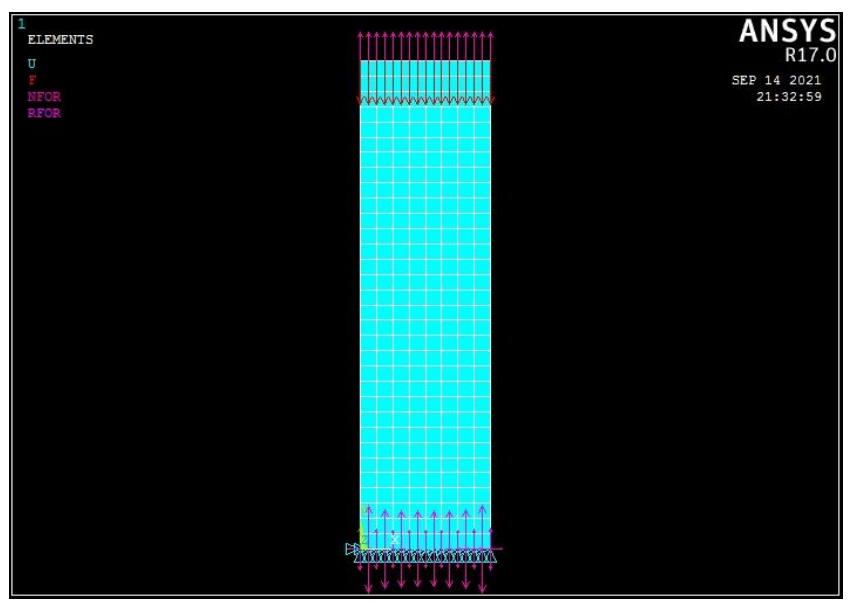




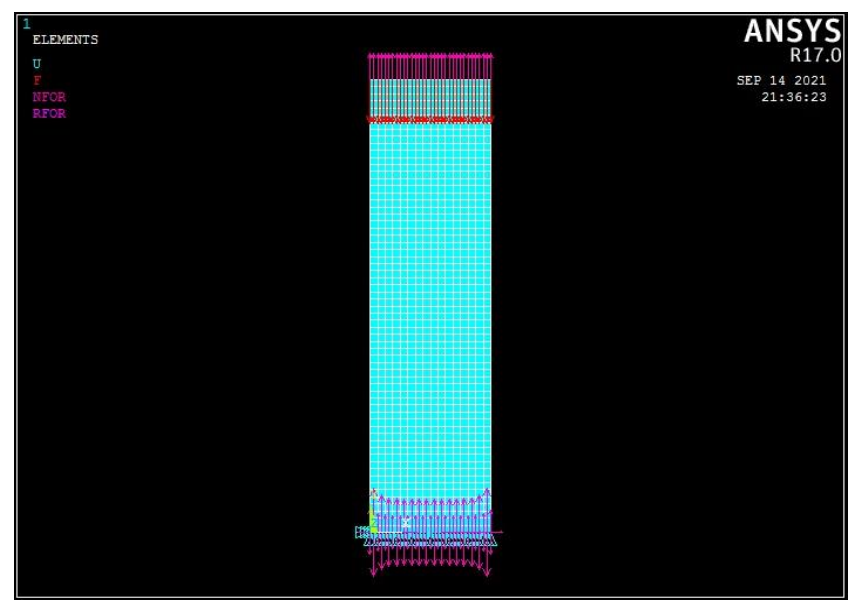

Figure 4. Design of boundary conditions on A1, A2, and A3

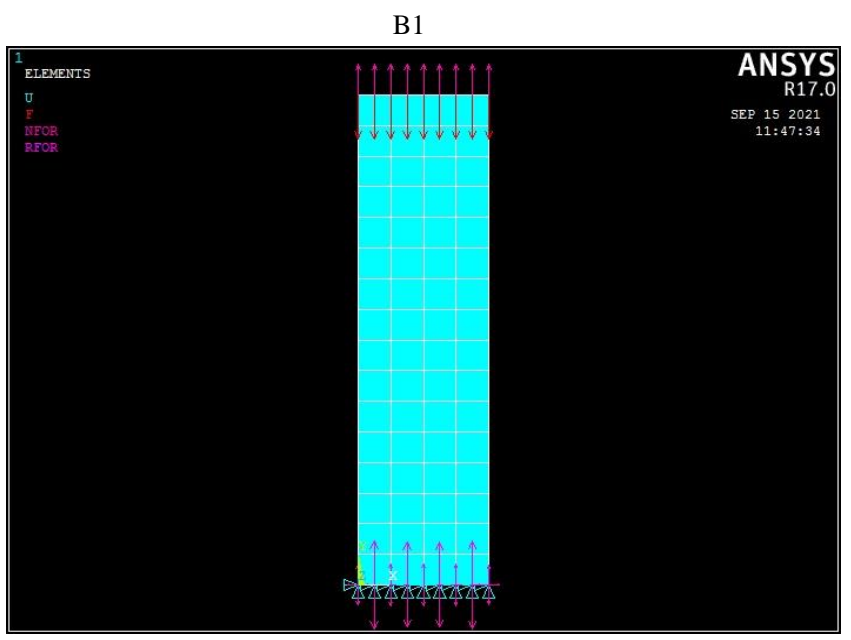

B2

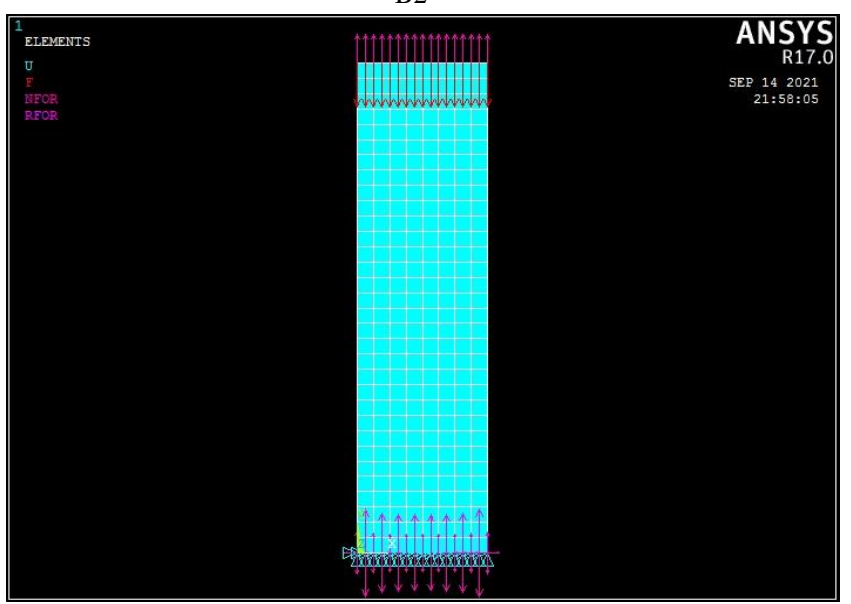




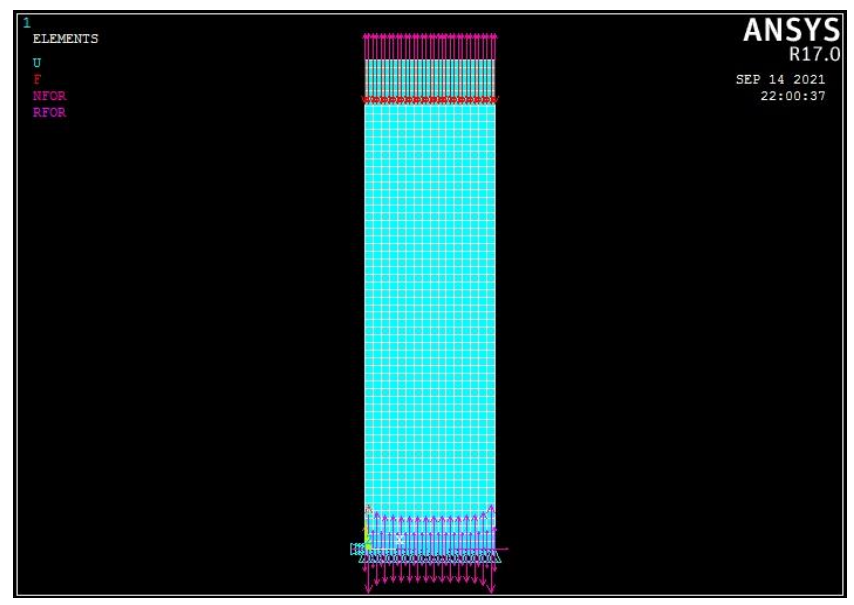

Figure 5. Design boundary conditions on B1, B2, and B3

\section{Results and Discussion}

According to the results of numerical analysis, a map of the displacement distribution, and stress distribution in each of the retaining wall geometries, it can be seen that foundation structure tested horizontal and vertical displacements were well distributed in each geometry presented. Each stress distribution map generated by geometries 1 and 2 was shown in Figures 6 and 7.

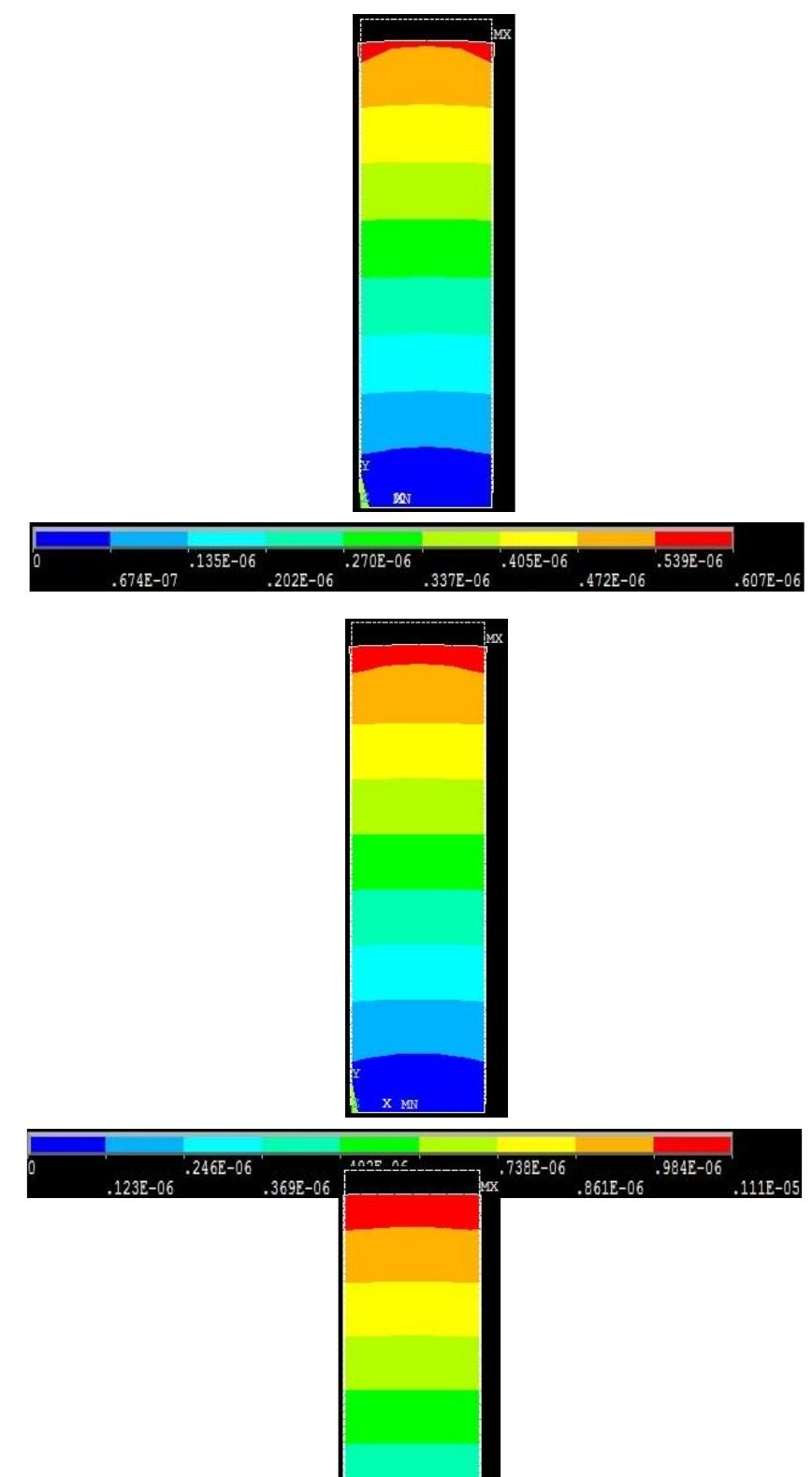




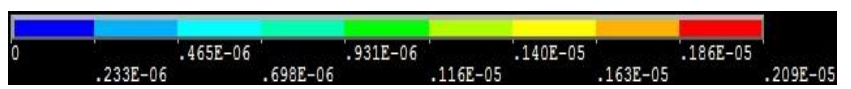

Figure 6. Pile foundation contours A1, A2, and A3
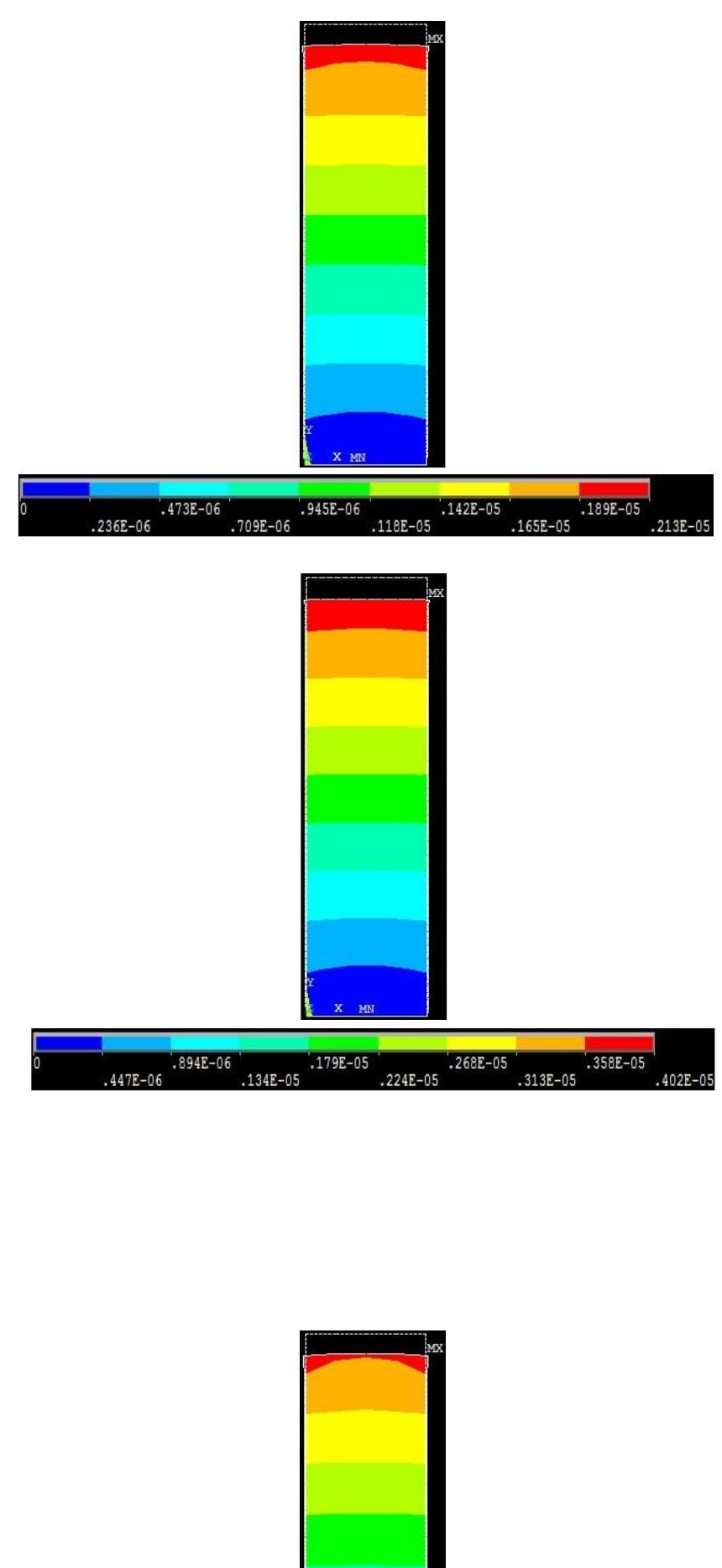


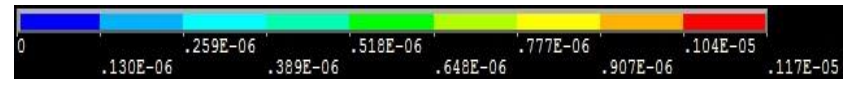

Figure 7. Contour of pile foundation B1, B2, and B3

Figure 8. showed the magnitude of the stress in each geometry. There were three repetitions for each model. The maximum values obtained by A3 and B3 for each of these geometries were 2.09e-6 MPa and 4.02e-6 MPa. Then, A2 and $\mathrm{B} 2$ were $1.11 \mathrm{e}-6 \mathrm{MPa}$ and 2.13e-6 MPa. Furthermore, for A1 and B1 these geometries were respectively 6.07e-7 $\mathrm{MPa}$ and $1.17 \mathrm{e}-6 \mathrm{MPa}$. Based on these results, it is known that the number of elements given to each geometry greatly affects the resulting value. The more element values, the higher the resulting calculation value. Therefore, the number of elements greatly affects the number of calculations when applying numerical methods. In addition, the comparison design presented is also very influential.

Based on the calculation results, ironwood has a stress yield that increases with the increase in the number of elements. B3 has 1024 elements, which was the highest number compared to B2 and B1 which have 256 elements and 64 elements, respectively. This was due to the large number of elements in B3.

The same result was also experienced by A3. The A3 sample has a total of 1024 elements. This number was more than A2 and A1 which have 256 elements and 64 elements. This was due to the large number of elements in A3.

Based on numerical calculations, it is known that the safety factor generated by the model is very large in the ironwood model. Ironwood is an alternative foundation material for houses in West Papua, because the ironwood model has a better safety factor than the matoa wood model. Another reason is because the ironwood model has material properties that are inherent to the surrounding environment compared to the matoa wood model.

From the two models, the ironwood sample has a good stress distribution value based on the results of numerical calculations. Ironwood samples have very small shift and stress values compared to matoa wood. This showed that the ironwood samples tested have good mechanical properties of the material when applied to the surrounding environment compared to matoa wood. Ironwood was known for its mechanical strength. However, this tree was widely spread in Kalimantan. This tree was separated from other trees and surrounded by a circular path of ironwood. Meanwhile, at the bottom of the tree, there was a hole in it. The type of wood from the ironwood tree was not easily weathered, both in water and on land. Due to that reason, this wood was widely used as a building material, especially for houses built on marshy land.

As for the matoa tree sample, it has less stress distribution values. However, the matoa tree was a native plant of Papua, widely spread in the forests of Papua. Generally, it grew naturally on clay-textured flat soils thus when it rained it got a bit waterlogged. By the community, this plant was often used as a fruit with a mixed taste of rambutan, longan and rambutan. It belonged to the rambutan family (Sapindaceae). However, if needed, the wood will be used as a building material, especially for residents' houses.

The harvest period for transplanted matoa trees will usually produce fruit at the age of 4 years, if matoa cultivation from seeds will take 6 years to bear fruit. Matoa fruit is ready to be harvested after 2 months from starting to flower. If used as wood, the matoa tree takes 10 years to be ready for use. Unlike the ironwood tree, ironwood seed germination took a long time, about 6-12 months with a relatively low percentage of success. Moreover, the fruit production per tree was generally low. Besides that, when using ironwood wood, shipping costs were expensive since the tree was only scattered in the forests of Kalimantan. Hence, the alternative was matoa tree wood.

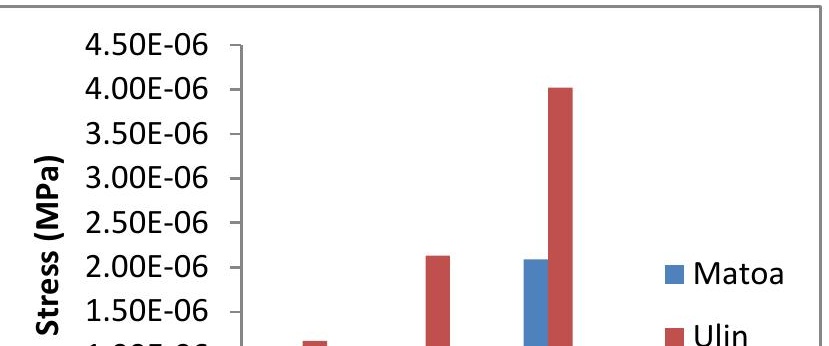


Figure 8. Stress value at each repetition

The force vectors generated by each model supported the values resulting from the shift and stress distributions. Figure 9 showed the style vectors of each model for matoa and ironwood. From the force vector, it was known that each geometry got a force that was evenly distributed on each side. When compared from the two models, it can be seen that the ironwood model has a good style vector. The direction of the force vector received by the ironwood model was still mostly perpendicular to the bottom, compared to the matoa wood model where the direction of the force vector has begun to bend. According to these results, the ironwood model was suitable if applied to the foundation of residents' houses. It was due to the ironwood model has compatible material properties when applied to the area, compared to the matoa wood model which experienced material degradation when applied. However, ironwood resources were not found in the West Papua. This was what hinders the use of ironwood as the foundation of people's houses, compared to matoa wood which was widely available in the West Papua region. In addition, it was easy to cultivate and many benefits provided to the surrounding community.
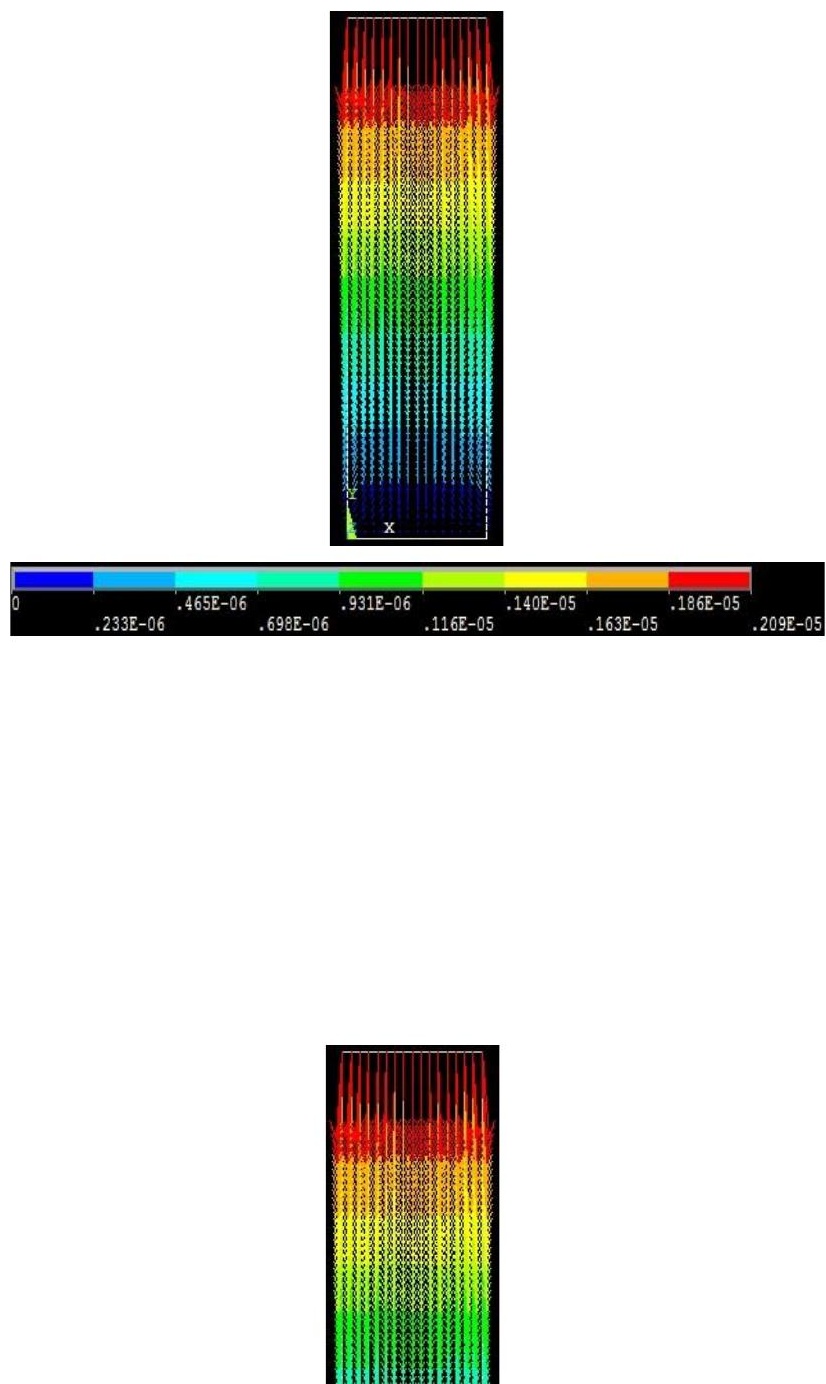


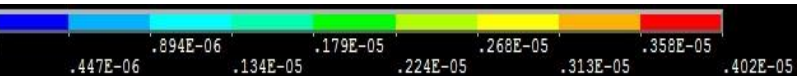

Figure 9. The pile foundation style vector of all samples

\section{Conclusion}

Based on the research that has conducted, matoa tree wood composite is suitable if used as a house foundation. The results obtained showed that the resistance to mechanical compression test of ironwood composite was greater than that of matoa wood. The results obtained are matoa wood and ironwood, respectively A1 $=6.07 \mathrm{e}-07 \mathrm{MPa}, \mathrm{A} 2=1.11 \mathrm{e}-$ $06 \mathrm{MPa}$, and A3 = 2.09e-06 MPa, and B1 = 1.17e -06 MPa, B2 = 2.13e-06 MPa, and B3 = 4.02e-06 MPa. However, when it was seen from the perspective of the impact on the environment, matoa tree has environmentally friendly properties that are effective and efficient. This is supported by the nature of the matoa tree which is easy to cultivate and its roots do not damage other plants.

Generally, regarding the results of grafting, harvesting can be performed after 4 years from the time of grafting. In contrast to ironwood trees, ironwood seed germination takes a long time of about 6-12 months with a relatively low percentage of success. In addition, the growth rate of ironwood trees tends to be slow, it was only growing an average of $0.0058 \mathrm{dm}$ per year. Thus, it is considered less economical to cultivate it as a plant on productive land. Therefore, matoa tree wood is an appropriate material if it is used as a house foundation material.

\section{References}

Karyaatmaja, B. and Suripatty, B.A. Matoa (Pometia spp.) di Irian Jaya: Informasi Teknis. Buletin Matoa: Visi dan Misi BPK Manokwari. Manokwari. 1997.

Dinas Kehutanan Daerah Tingkat I Irian Jaya. Mengenal Beberapa Jenis Kayu Irian Jaya.Dinas Kehutanan Daerah Tingkat I Irian Jaya. Jayapura. 1976.

Wowor, A.E., Thomas, A. and Rombang, J.A. KANDUNGAN UNSUR HARA PADA SERASAH DAUN SEGAR POHON (MAHONI, NANTU DAN MATOA), EUGENIA, vol. 25, no. 1, pp. 1-7, 2020.

Agus Haerudin and Farida, Matoa (Pometia Pinnata) Wood Shavings as The Natural Color Substance of Cotton Fiber Batik, Dinamika Kerajinan dan Batik, vol. 34, no. 1, pp. 43-52, 2017.

Ngajow, M., Abidjulu, J. and Kamu, V.S., Pengaruh Antibakteri Ekstrak Kulit Batang Matoa (Pometia pinnata) terhadap Bakteri Staphylococcus aureus secara In vitro, Jurnal MIPA, vol. 2, no. 2, pp. 128, 2013.

Hajar, S., Rahmah, W., Putri, E. M., Ressandy, S. S., and Hamzah, H., POTENSI EKSTRAK BUAH MATOA (POMETIA PINNATA) SEBAGAI SUMBER ANTIOKSIDAN: LITERATUR REVIEW, Jurnal Farmasi Sains dan Praktis, vol. 7, no. 1, pp. 59-66, 2021.

Sugiarto, Wardani, P. K., Setyono, P., Mahajoeno, E., and Sunarto, The Influence of Mycorrhiza and Organic Ferlitizer to The Growth of Seedling Matoa (Pometia pinnata), Universitas Sebelas Maret Institusional Repositori, Available: https://eprints.uns.ac.id/id/eprint/12622, September 01, 2021.

Nakai, T., Mechanical properties of Tropical Woods, Japan Agricultural Research Quarterly, vol. 18, no. 4, pp. 315$323,1985$.

Nurfansyah, N., Saud, M. I., Wastuti, P., W., Aini, A., Q., and Agusniansyah, N., PERKEMBANGAN PONDASI TIANG KAYU PADA RUMAH TINGGAL DI BANJARMASIN, INFO-TEKNIK, vol. 21, no. 2, pp. $199,2020$.

Rifky, A., STUDI PERBANDINGAN PONDASI KAYU GALAM DAN MINI PILE PADA BANGUNAN PERUMAHAN TIPE RED VALERIAN KOMPLEK CITRA GARDEN BANJARMASIN, JURNAL REKAYASA SIPIL, vol. 2, no. 1, pp. 8, 2014. 
Lestari, Zain, Z., Rudiyono, and Irwin, MENGENAL ARSITEKTUR LOKAL: KONSTRUKSI RUMAH KAYU DI TEPIAN SUNGAI KAPUAS, PONTIANAK, LANGKAU BETANG: JURNAL ARSITEKTUR, vol. 3, no. 2, pp. $1-11,2016$.

Khaliesh, H. and Gultom, B. J., PONDASI TIANG TONGKAT SEBAGAI ADAPTASI KONSTRUKSI LAHAN GAMBUT DI KALIMANTAN BARAT, ILMU DAN TEKNOLOGI MATERIAL BANGUNAN, Available: http://e-journal.uajy.ac.id/10837/, September 01, 2021.

Turin, T. A., Arifin, B. M. E., and Tohir, M., PERENCANAAN PONDASI TIANG PANCANG PADA PEMBANGUNAN RESERVOIR DAN TANGKI WTP KAPASITAS 250 RIBU LITER PDAM KEC. LOAKULU KAB. KUTAI KARTANEGARA, TEKNIK SIPIL DAN ARSITEKTUR, vol. 1, no. 1, pp. 276-291 , 2017.

J. E. Gordon, The New Science of Strong Materials, Princeton University Press, New Jersey, 2019.

C. M. Clemons and D. F. Caufield, Wood Flour. In Functional fillers for plastics, Germany, Willey, pp. 249-270, 2005.

S. Aydin, K. Ramyar, and M. Y. Yardimci, Mechanical properties of four timber species commonly used in Turkey, Turkish journal of engineering and enviournmental science, vol. 31, pp. 19-27, 2007.

M. R. Peaez-Samaniego, V. Yadama, E. Lowell and R. Espinoza-Herrera, A review of wood thermal pretreatments to improve wood composite properties, Wood Science Technology; vol. 47, no. 6, pp.1321-1322, 2013.

N. Chand and M. Fahim, Wood reinforced polymer composites. In Tribology of Natural Fiber Polymer Composites, Cambridge, England, Woodhead Publishing Limited, pp. 180-196, 2008.

N. Ayrilmis, M. Tasdemir and T. Akbulut, Water absorption and mechanical properties of PP/HIPS hybrid composites filled withwood flour, Polymer Composites, vol. 38, no. 5, pp. 863-69, 2017.

AlShuhail, K., Aldawoud, A., Syarif, J., and Abdoun, I. A., Enhancing the performance of compressed soil bricks with natural additives: Wood chips and date palm fibers, Construction and Building Materials, vol. 295, pp. 123611, 2021.

Yoresta, F. S., PHYSICAL AND MECHANICAL PROPERTIES OF BLACK WOOD (EBONY) AS A CONSTRUCTION MATERIAL, LANGKAU BETANG: JURNAL ARSITEKTUR, vol. 2, no. 1, pp. 22-28, 2015.

Saefudin, A., PEMANFAATAN KAYU SEBAGAI BAHAN STRUKTUR BANGUNAN, Menara: Jurnal Teknik Sipil, vol. 2, no. 1, pp. 23-36, 2007.

Anshari, B., Guan, Z. W., Kitamori, A., Jung, K., and Komatsu, K., Structural behaviour of glued laminated timber beams pre-stressed by compressed wood, Construction and Building Materials, vol. 29, pp. 24-32, 2012.

Karagiannis, V., Málaga-Chuquitaype, C. and Elghazouli, A.Y., Modified foundation modelling of dowel embedment in glulam connections, Construction and Building Materials, vol. 102, pp. 1168-1179, 2016.

Bekhta, P., Krytofiak, T., Proszyk, S., and Lis, B., Adhesion strength of thermally compressed and varnished wood (TCW) substrate', Progress in Organic Coatings, vol. 125, pp. 331-338, 2018.

El-Houjeyri, I., Thi, V-D., Oudjene, M., Khelifa, M., Rogaume, Y., Sotayo, A., and Guan, Z., Experimental investigations on adhesive free laminated oak timber beams and timber-to-timber joints assembled using thermomechanically compressed wood dowels, Construction and Building Materials, vol. 222, pp. 288-299, 2019.

Zheng, T., Yan, H., Li, S., Cheng, Y., Zou, L., and Hu, Y., Compressive behavior and failure modes of the woodbased double X-type lattice sandwich structure, Journal of Building Engineering, vol. 30, pp. 101176, 2020.

Huang, C., Chui, Y., Gong, M., and Chana, F., Mechanical behaviour of wood compressed in radial direction: Part II. Influence of temperature and moisture content, Journal of Bioresources and Bioproducts, vol. 5, no. 4, pp. 266275,2020 .

Karagöz Işleyen, Ü. and Kesik, H. İ., Experimental and numerical analysis of compression and bending strength of old wood reinforced with CFRP strips, Structures, vol. 33, pp. 259-271, 2021.

Bora, D., Narang, D. and Patni, M.S., Investigating the shear and compressive behaviour of the pine wood ash casting sand', Materials Today: Proceedings, pp. S2214785321011020, 2021.

Acosta, A. P., Barbosa, K. T., Amico, S. C., Missio, A. L., Delucius, R. de A., and Gatto, D. A., Improvement in mechanical, physical and biological properties of eucalyptus and pine woods by raw pine resin in situ polymerization, Industrial Crops and Products, vol. 166, pp. 113495, 2021.

Fan, C, Liu, H, Cao, J and Ling, HI, Responses of Reinforced Soil Retaining Walls Subjected to Horizontal and Vertical Seismic Loadings, Soil Dynamics and Earthquake Engineering, vol. 129, pp. 105969, 2019.

Ras, A and Bekkouche, A, Study of Soil-Retaining Wall Interaction by The Contact Finite Element Method, International Society for Soil Mechanics and Geotechnical Engineering, pp. 651-654, 2006, Available: https://www.issmge.org/search?keyword=Study+of+soil-retaining+wall+interaction+by+the+contact+finite, September 01, 2021. 
Cakir, T, Dynamic Analysis of A Cantilever Retaining Wall Including Soil-Structure Interaction, Conference: International Conference on Civil and Environmental Engineering (ICOCEE), , , , 2015, , https://www.researchgate.net/publication/292962689_Dynamic_Analysis_of_A_Cantilever_Retaining_Wall_In cluding_Soil-Structure_Interaction, September 01, 2021.

Salem, AN, Ezzeldine, OY and Amer, MI, Seismic Loading on Cantilever Retaining Walls: Full-Scale Dynamic Analysis, Soil Dynamics and Earthquake Engineering, vol. 130, pp. 105962, 2020.

Dongare, SP, Gandhi, PR, Gosavi, SS, Redkar, PA and Shaikh, R, Study on Comparative Design of Retaining Wall Structures and Analysis it In ANSYS APDL Software, International Research Journal of Engineering and Technology (IRJET), vol. 06, no. 04, pp. 3383-3393, 2019.

Garavand, MA, Saberi, A and Ghezelbash, MS, "Seismic Analysis of Retaining Wall Structures," 5th International Conferences on Recent Advances in Geotechnical Earthquake Engineering and Soil Dynamics, San Diego, USA, 28 May, 2010, pp. , https://scholarsmine.mst.edu/icrageesd/05icrageesd/session06/11, September 01, 2021.

Cakir, T, Finite Element Based Investigation of Backfill Effects on Seismic Behavior of A Cantilever Wall, Procedia Earth and Planetary Science, vol. 15, no. , pp. 231-236, 2015.

Jia, X, Xu, J and Sun, Y, Deformation Analysis of Reinforced Retaining Wall Using Separate Finite Element, Discrete Dynamics in Nature and Society, vol. 2018, no. , pp. 9 pages, 2018.

Al-Shukur, AHK and Al-Rammahi, AMA, Optimum Design of Gravity Wall Founded on Specially Random Soil Subjected to Earthquake Load, Journal University of Kerbala, vol. 15, no. 2, pp. 212-224, 2017.

Jadhav, PR and Prashant, A, Computation of Seismic Translational and Rotational Displacements of Cantilever Retaining Wall with Shear Key, Soil Dynamics and Earthquake Engineering, vol. 130, pp. 105966, 2020.

Belal, AM and George, KP, Finite Element Analysis of Reinforced Soil Retaining Walls Subjected to Seismic Loading, 12th World Conference on Earthquake Engineering, 2000, Available: https://www.semanticscholar.org/paper/FINITE-ELEMENT-ANALYSIS-OF-REINFORCED-SOIL-WALLSTO-Belal-George/c5bc3739967704d76d7e822afba0aef82d90d136, September 01, 2021.

Ooi, JY and Rotter, JM, Wall Pressures in Squat Steel Silos from Simple Finite Element Analysis, Computers \& Structures, vol. 37, no. 4, pp. 361-374, 1990.

Xu, P, Hatami, K and Jiang, G, Seismic Rotational Stability Analysis of Reinforced Soil Retaining Walls, Computers and Geotechnics, vol. 118 , pp. 103297, 2020.

Bhaskar, K., Jayabalakrishnan, D., Kumar, M. V., Sendilvelan, S., and Prabhahar, M., Analysis on mechanical properties of wood plastic composite, Materials Today: Proceedings, vol. 45, pp. 5886-5891, 2021.

Anshari, B., Guan, Z.W. and Wang, Q.Y., Modelling of Glulam beams pre-stressed by compressed wood, Composite Structures, 165, pp. 160-170, 2017.

Ruzuqi, R, Analysis Two Dimension Heat Conduction in Functionally Graded Materials using Finite Element Methods, International Journal of Science and Society, vol. 2, no. 2, pp. 91-101, 2020.

Darmawan, W., Rahayu, I., Nandika, D., and Marchal, R., WEAR CHARACTERISTICS OF WOOD CUTTING TOOLS CAUSED BY EXTRACTIVE AND ABRASIVE MATERIALS IN SOME TROPICAL WOODS, Journal of Tropical Forest Science, vol. 23, no. 3, pp. 10, 2011.

\section{Biography}

Eko Tavip Maryanto master of civil engineering as lecturer and head of study program at the civil engineering study program, faculty of science and technology, Muhammadiyah University of Sorong (UNIMUDA), a middle expert on road and bridge supervision from HPJI, member of IAMPI association of Indonesian Project Management Experts, intermediate professional engineer at the Indonesian Engineers Association (PII), secretary of the INKINDO West Papua Organization Advisory Council, a doctoral candidate in Civil Engineering at Sebelas Maret University Surakarta (UNS). Now the urban Heat island research concentration is on urban infrastructure with a local wisdom approach.

Rezza Ruzuqi Lecturer at the Marine and Fisheries Polytechnic of Sorong, the Research and Human Resources Agency of the KKP. He was born in Surabaya and born on October 19, 1991. My father's name is Major (Purn.) Sutarman, S.H. and my mother's name is Macheasy. Alumni of Materials and Metallurgical Engineering Institute of Technology Sepuluh Nopember Surabaya an interest in FGM (Functionally Graded Materials) Composite Material Modeling (MT, 2018), and alumni of the Physics Study Program Universitas Airlangga Surabaya in the field of Material Physics with the research theme Nickel-based Superalloy Materials (S.Si. ., 2015). Has been an Assistant Lecturer for Digital and Analog Electronics at Airlangga University (2014-2015), worked in several private contractor companies as field supervisors and admins (2015-2017). KENCANA TRUSS Surabaya Head of Factory (2018), became a research member in project making frangible bullets (2017) and was active as a reviewer in several 
international journals. Involve in the field of composite materials, especially in the marine and fisheries, and civil sectors. Active research projects on the development of fiber boat materials in the West Papua region, the development of the Salt Water Lamp Battery material, the development of natural composite materials based on local resources as building poles in the West Papua region, and the development of heat-resistant materials based on local resources for settlements in the West Papua region. Has several international journals in the field of science and edits scientific works into an ISBN book. 




